\title{
The Diagnostic Value of Ischemia-modified Albumin in Prostate Cancer
}

\author{
Prostat Kanserinde Iskemi-modifiye Albümin'in Tanısal Değeri \\ (1) Rahmi Aslan, (1) Recep Eryılmaz, (1) Mehmet Sevim, (1) Murat Demir*, (D) Kerem Taken \\ Yüzüncü Yıl University Faculty of Medicine, Department of Urology, Van, Turkey \\ *University of Health Sciences, Van Traning and Research Hospital, Clinic of Urology Van, Turkey
}

\section{Abstract}

Aim: The aim of this study was to investigate whether serum ischemia-modified albumin (IMA) levels have a diagnostic value in prostate cancer (Pca).

Methods: Thirty primary Pca patients and 30 age-matched healthy male subjects were included in this prospective casecontrol study. The patients were selected from the urology clinic of a tertiary university hospital. Healthy men included in the control group were selected from hospital staff and patient relatives. Patients with severe chronic diseases and other malignancies were excluded. Serum IMA level was measured using the colorimetric method. The results were reported in absorbance unit (ABSU).

Results: Serum IMA levels were significantly higher in the study group when compared to the control group $(0.843 \pm 0.76$ and $0.443 \pm 0.49 \mathrm{ABSU}$, respectively; $p=0.002)$. The mean IMA value in patients with a Gleason score $\geq 7(1.08 \pm 0.053 \mathrm{ABSU})$ was significantly higher than in patients with Gleason score $\leq 6$ (IMA 0.418 $\pm 0.64 \mathrm{ABSU}$ ). According to the receiving operating characteristic (ROC) analysis, when the cut-off value was $A B S U=0.57$, the sensitivity and specificity were $80 \%$ and $56.7 \%$, respectively.

Conclusion: Serum concentrations of IMA are significantly elevated especially in clinically significant Pca patients. Its high sensitivity (80\%) in ROC analysis suggests that IMA can be used an ancillary biomarker in diagnosis.

Keywords: IMA, prostatic cancer, diagnosis, bio-marker
Amaç: Bu çalışmada Prostat kanserinde (Pca) serum iskemi modifiye albümin (IMA) düzeylerinin tanısal bir rolü olup olmadığının araştıııması amaçlandı.

Yöntemler: Bu prospektif olgu kontrol çalışmasına 30 primer Pca hastası ve kontrol grubuna 30 sağlıklı erkek birey (yaşla eşleştirilmiş) dahil edildi. Hastalar, üçüncü basamak bir üniversite hastanesindeki üroloji kliniğinden seçildi. Kontrol grubuna alınan sağlıklı erkekler ise hastane çalışanlarından ve hasta yakınları arasından seçildi. Ciddi kronik hastalıkları ve başka malignitesi olan hastalar çalışma dışı bırakıldı. Serum IMA seviyesi kolorimetrik yöntem ile ölçüldü ve sonuçlar absorbans birimi (ABSU) olarak verildi

Bulgular: Çalışma grubundaki hastalarda ortalama IMA düzeyi kontrol grubu ile karşılaştııılığında istatiksel olarak anlamlı

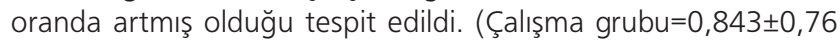
kontrol grubu=0,443 $\pm 0,49$ ABSU $p=0,002$ ) Gleason skoru (GLS) $\geq 7$ olan hastaların ortalama IMA $(1,08 \pm 0,053 \mathrm{ABSU})$ düzeyleri, $\mathrm{GLS} \leq 6$ olan hastalara (iMA=0,418 $\pm 0,64 \mathrm{ABSU}$ ) göre istatiksel olarak anlamlı oranda yüksek bulundu. Alıcı işletim karakteristiği (ROC) analizine göre eğri altında kalan alan \%73,1 bulundu. Cutt-off değeri 0,57 ABSU alındığında sensivite $\% 80$ ve spesifite $\% 56,7$ bulundu.

Sonuç: Verilerimiz özellikle klinik olarak anlamlı Pca hastalarında serum iMA seviyelerinin istatiksel olarak anlamlı oranda yüksek olduğunu göstermektedir. Aynı zamanda iMA'nın ROC analizine iMA senstivitesinin \%80 görülmesi tanıda yardımcı bir biyobelirteç olarak kullanılabilirliğini desteklemektedir.

Anahtar Sözcükler: IMA, prostat kanseri, tanı, biyomarker
Address for Correspondence/Yazışma Adresi: Rahmi Aslan, Yüzüncü Yıl University Faculty of Medicine, Department of Urology, Van, Turkey E-mail: draslan65@hotmail.com ORCID: orcid.org/0000-0002-4563-0386 Received/Geliş Tarihi: 30 May 2019 Accepted/Kabul Tarihi: 16 October 2019
${ }^{\circ}$ Copyright 2020 by The Medical Bulletin of istanbul Haseki Training and Research Hospital The Medical Bulletin of Haseki published by Galenos Yayınevi. ${ }^{\circ}$ Telif Hakkı 2020 istanbul Haseki Eğitim ve Araştırma Hastanesi Haseki Tıp Bülteni, Galenos Yayınevi tarafından yayınlanmıştır. 


\section{Introduction}

Prostate cancer (Pca) is currently accepted as one of the most important health problems affecting males. Pca is the second most common cancer with more than 1.1 million new cases occurring worldwide. This accounts for approximately $15 \%$ of all diagnosed cancers in men (1). Pca is followed by lung and colorectal cancers respectively. Moreover, Pca is the second most common cause of cancer deaths in men. (2-4). Prostate-specific antigen (PSA) test is a molecular test discovered 40 years ago and is the most commonly used to detect the disease and evaluate recurrence. Although this test is very important in early diagnosis, it is recently criticized for being not specific cancer, revealing false positive results and leading often to overdiagnosis $(5,6)$. Today, PSA value is determined by visual methods and histopathological scoring. However, all these methods are still unsatisfactory to determine the individual prognosis. This sometimes leads to unnecessary treatment and sometimes obstacle to necessary treatment (7). Recently, trials tend to investigate biomarkers that are safe to solve these clinical problems (8).

There are many evidences that demonstrate effect of reactive oxygen species (ROS) in the development of cancer. ROS consist of hydroxyl radicals, superoxide anion radicals and lipid peroxide radicals. High concentrations of ROS may cause both tissue damage and DNA damage by inducing oxidative stress. ROS is claimed to act as secondary messengers in intracellular signaling cascades in the cell and to provide cancer cell viability (9-12).

Ischemia-modified albumin (IMA) is an altered type of serum albumin generated by ROS $(13,14)$. IMA is accepted as a reliable biomarker of oxidative stress (15). Elevated serum IMA is demonstrated in various diseases associated with inflammation and oxidative stress. Moreover, serum IMA level has been shown to increase in stomach cancer, soft tissue cancer, neuroblastoma and benign prostatic hyperplasia (BPH) (16-18).

In this study, we aimed to compare serum IMA levels between patients with Pca and controls and investigated the value of serum IMA levels in the diagnosis of Pca.

\section{Methods}

\section{Study Design}

This study was approved by our local ethics committee [Van Yüzüncü Yıl University, Faculty of Medicine (approval no: 01)]. Thirty primary Pca patients and 30 age-matched healthy male subjects were included in this prospective case-control study. The patients were selected from the urology clinic of a tertiary university hospital. Patients with a high serum PSA value ( $\geq 4 \mathrm{ng} / \mathrm{mL}$ ) and/or abnormal digital rectal examination findings underwent transrectal ultrasound (TRUS)-guided biopsy. All patients underwent a 12-core biopsy protocol, including six parasagittally and six laterally targeted cores covering the base, mid-zones, and apex. The biopsy samples were numbered separately and analyzed by an uropathologist. Patients who were diagnosed with primary Pca after TRUS-guided biopsy were included in the study. Healthy men included in the control group were selected from hospital staff and patient relatives. All volunteers in the control group were screened for Pca, BPH, other malignancies and chronic diseases. Patients with preoperative severe comorbidities, such as severe cardiac and neurological diseases, other malignancies, acute and chronic infectious diseases, acute organ failure, chronic obstructive pulmonary disease and other ischemic and immunosuppressive diseases, were excluded from the study. Moreover, individuals with abnormally low or high serum albumin levels ( $<20$ or $>55$ $\mathrm{g} / \mathrm{L}$ ) were also excluded from the study.

Demographic characteristics and clinic and histopathologic data of both groups were recorded and analyzed comparatively. Written informed was obtained from all the participants.

Blood samples were drawn from the antecubital vein into EDTA and NA-citrate blood tubes and centrifuged at $3000 \mathrm{rpm}$ for 10 minutes. The serum and plasma specimens were stored at $-80{ }^{\circ} \mathrm{C}$ until the biochemical analysis.

\section{Measurement of IMA}

Serum IMA level was measured with colorimetric analysis that is developed by Bar-Or et al. (19). To measure serum IMA, $50 \mathrm{IL}$ cobalt chloride is added to $200 \mu \mathrm{L}$ of serum, vigorously mixed and the mixture solution is incubated for 10 minutes to ensure cobalt binds to albumin appropriately. Next, $50 \mathrm{uL}(1.5 \mathrm{mg} / \mathrm{mL})$ dithiothretol (DTT) solution (Sigma-Aldrich, Germany) is added as coloring agent and mixed vigorously then incubated at room temperature for 2 minutes. Finally, $1.0 \mathrm{~mL}$ of $0.9 \% \mathrm{NaCl}$ is added. One colorimetric control is prepared for each sample. $50 \mu \mathrm{L}$ of distilled water is used for control samples instead of $50 \mu \mathrm{L}$ of $1.5 \mathrm{mg} / \mathrm{mL}$ DTT. Resultant color complex is measured with spectrophotometric method in wavelength of $470 \mathrm{~nm}$. Results are reported in absorbance units (ABSU).

\section{Statistical Analysis}

All data were analyzed using the SPSS version 20 (IBM SPSS Statistics for Windows, Version 20.0, IBM Corp., NY, USA). Continuous variables were expressed as mean \pm standard deviation or median value with the range of values when a normal distribution or a non-normal distribution was present, respectively. Categorical variables were expressed as ratio and frequency. The difference in 
the level of IMA between the groups was evaluated using the ANOVA. Multiple comparisons were made using the Tukey HSD test. The Student's t-test or Mann-Whitney $U$ test was used in the binary comparison of the groups where appropriate. The capacity of serum IMA values in predicting presence of Pca was analyzed using ROC curve analysis. A p value of less than 0.05 was considered statistically significant.

\section{Results}

There was no significant difference in body mass index comorbidities, prostate volume and serum albumin level between the patients and controls (Table 1).

IMA levels were analyzed in study and control groups. The mean IMA level in Pca patients was statistically significantly higher than in controls $(0.843 \pm 0.76$ and $0.443 \pm 0.49 \mathrm{ABSU}$, respectively $(p=0.002)$ (Figure 1$)$.

The patients in study group were divided into two subgroups according to Gleason score (GS). The mean IMA level in patients with $G S \geq 7(1.08 \pm 0.053 \mathrm{ABSU})$ was significantly higher than in patients with $\mathrm{GS} \leq 6(0.418 \pm 0.64$ ABSU). The mean IMA level in patients with clinical stage 1 and stage $\geq 2$ was $0.457 \pm 0.41$ and $1.13 \pm 0.18$ ABSU, respectively. The difference in IMA value between these two subgroups was statistically significant $(p=0.002)$. On the other hand, when mean IMA was compared between patients with stage 1 disease and GLS score $\leq 6$ and the control group no statistically significant difference was detected ( $p>0.05$ ) (Table 2).

In the study, according to ROC curve analysis results (figure 2), the area under curve was $73.1 \%$. When the cutoff value was $A B S U=0.57$, sensitivity and specificity were $80 \%$ and $56.7 \%$, respectively (Figure 2 ).

When the correlation between PSA values and IMA

\begin{tabular}{|l|l|l|l|}
\hline \multicolumn{4}{|l|}{ Table 1. Demographic and clinical characteristics of the patients } \\
\hline & $\begin{array}{l}\text { Working } \\
\text { group }\end{array}$ & $\begin{array}{l}\text { Control } \\
\text { group }\end{array}$ & $\mathbf{p}$ \\
\hline Age (years), mean \pm SD & $63.4 \pm 8.6$ & $61.8 \pm 10.5$ & $>0.05$ \\
\hline BMI (kg/m²), mean \pm SD & $27.8 \pm 6.02$ & $27.08 \pm 2.9$ & - \\
\hline PSA (ng/mL), mean \pm SD & $18.07 \pm 15.3$ & $2.1 \pm 0.12$ & $<0.001$ \\
\hline $\begin{array}{l}\text { Prostatic volume, } \\
\text { mean } \pm \text { SD }\end{array}$ & $73.7 \pm 46.8$ & $71.3 \pm 31.9$ & $>0.05$ \\
\hline $\begin{array}{l}\text { Comorbidities (DM- } \\
\text { dyslipidemia CVD), n (\%) }\end{array}$ & $17(56.6 \%)$ & $15(50.0 \%)$ & $>0.05$ \\
\hline Albumin (g/L) & $29.6 \pm 5.2$ & $28.94 \pm 6.2$ & $>0.05$ \\
\hline Gleason score $\leq \mathbf{6 , n}$ (\%) & $11(36.6 \%)$ & - & - \\
\hline Gleason score $\geq 7, \mathbf{n}$ (\%) & $19(63.4 \%)$ & - & - \\
\hline Clinical stage 1, n (\%) & $14(46.6 \%)$ & - & - \\
\hline Clinical Stage 2-4, n (\%) & $16(53.33 \%)$ & - & - \\
\hline $\begin{array}{l}\text { SD: Standard deviation. BMI: Body mass index. DM: Diabetes Mellitus. CVD: } \\
\text { Cardiovascular disease. PSA: Prostate specific antigen }\end{array}$ \\
\hline
\end{tabular}

values in patient group was investigated, approximately $70 \%$ positive correlation was observed $(p<0.001)$ (Figure 3).

\section{Discussion}

Development of cancer is a multi-stage process. ROSmediated DNA damage plays an important role, especially in the initial and advanced stages of this process (20). ROS consist of hydroxyl radicals, peroxide and superoxide and they are also generated by healthy cells. However, tissue or DNA damage develops if ROS is generated excessively (10). Hydroxyl radicals cause base modification and genomic instability by interacting with purines and pyrimidines (20). Moreover, it has been suggested that they activate intracellular signal pathways and increase the durability of cancer cells (10).

IMA is considered a biomarker of oxidative stress. Ischemic, inflammatory diseases and diseases such as stomach, colorectal and bladder cancers have been shown to increase serum IMA levels.

Many in vitro and in vivo studies showed that oxidative stress caused by overproduction of ROS or impaired antioxidant mechanisms play a key role in the pathogenesis

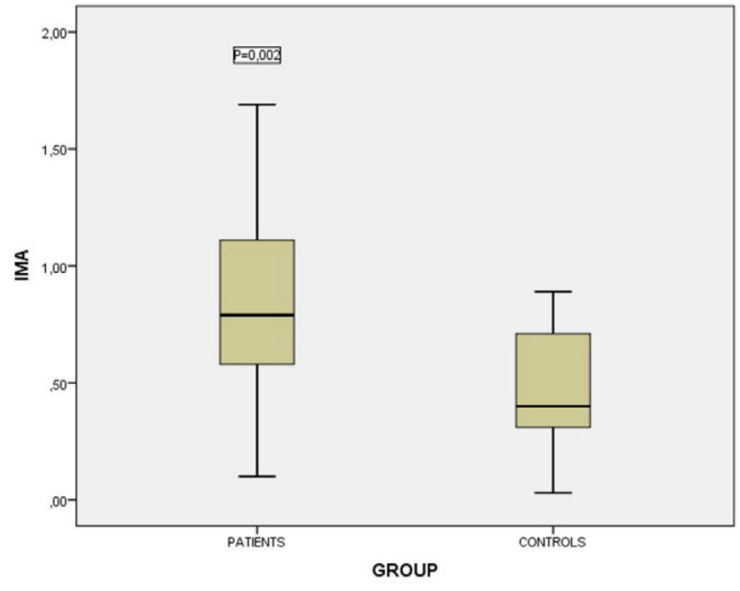

Figure 1. IMA levels in groups

IMA: Ischemia-modified albumin

\begin{tabular}{|c|c|c|c|}
\hline & $\begin{array}{l}\text { Study group } \\
\text { (Average IMA } \\
\text { level, ABSU) }\end{array}$ & $\begin{array}{l}\text { Control group } \\
\text { Average IMA } \\
\text { level, ABSU) }\end{array}$ & $p$ \\
\hline Stage 1 & $0.457 \pm 0.41$ & \multirow[t]{5}{*}{$0.443 \pm 0.49$} & $>0.005$ \\
\hline Stage $2,3,4$ & $1.13 \pm 0.18$ & & $<0.001$ \\
\hline GL score $\leq 6$ & $0.418 \pm 0.64$ & & $>0.05$ \\
\hline GL score $\geq 7(7-10)$ & $1.08 \pm 0.053$ & & $<0.001$ \\
\hline Total patients & $0.843 \pm 0.76$ & & $p=002$ \\
\hline
\end{tabular}


of Pca $(21,22)$. In this study, we aimed to reveal out the relationship between IMA, a biomarker of oxidative stress, and Pca. We analyzed serum IMA in patients with primary Pca. We demonstrated that IMA was significantly higher in patients with Pca than in control group. On the other hand, we observed that IMA levels were significantly higher in patients with $G S \geq 7$. Moreover, it was observed that IMA levels were higher in patients with advanced stage (II,III,IV) Pca. We also found that IMA had a high positive correlation with PSA values in Pca patients. All

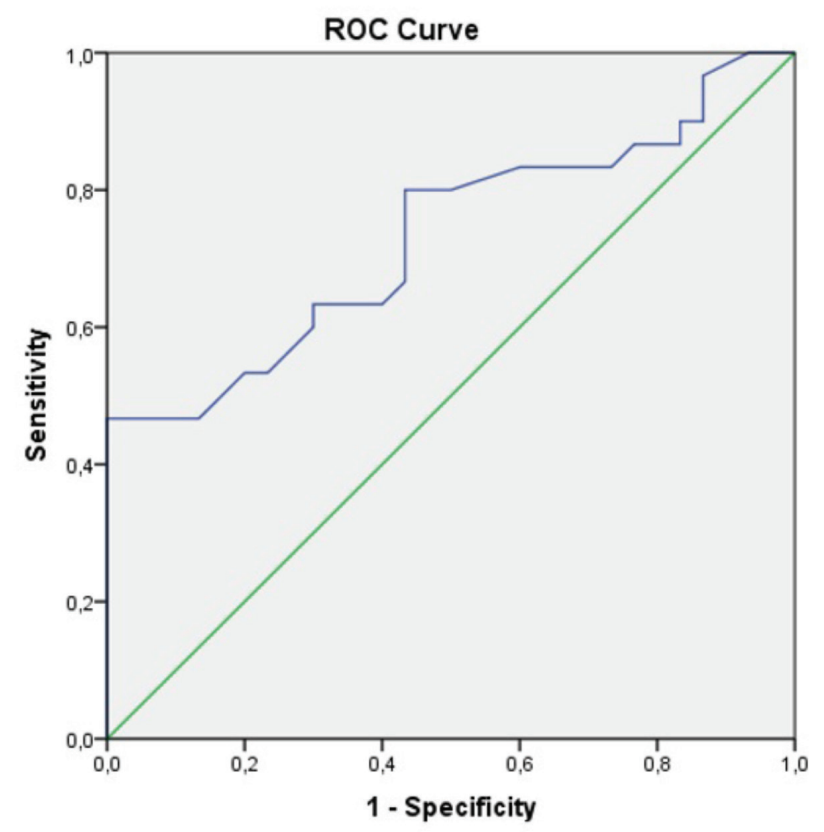

Figure 2. ROC Anaysis by IMA values in Pca patients ROC: Receiver operating characteristic, IMA: Ischemia-modified albumin, Pca: Prostate cancer

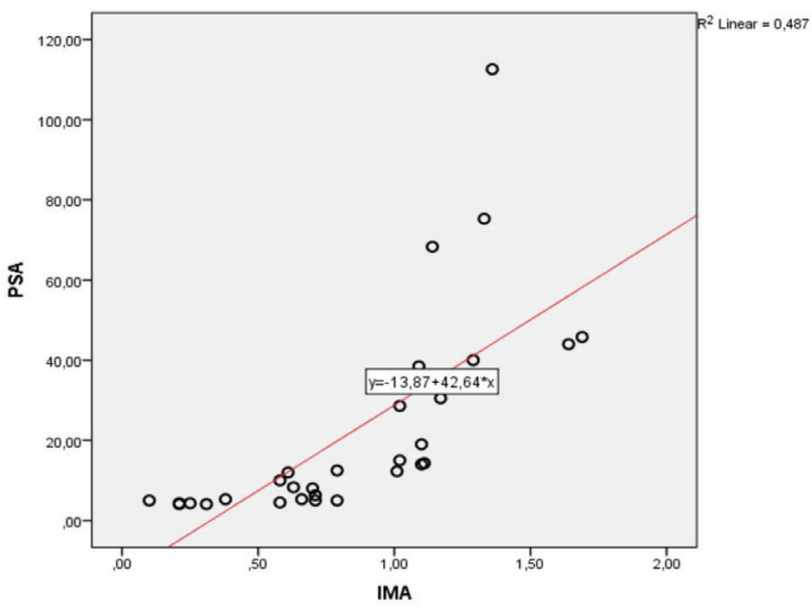

Figure 3. IMA and PSA correlation in Pca patients IMA: Ischemia-modified albumin, Pca: Prostate cancer these data show that IMA can be associated with especially aggressive and high-grade Pca.

According to current European guidelines, there are several evidence-based treatment options available for these patients. Reliable biomarkers are urgently needed to guide the pre-treatment decision process for PCa patients (23). The fact that sensitivity of IMA (when the cut-off value is 0.57 ) is $80 \%$ in the diagnosis of PCa according to $\mathrm{ROC}$ analyses may indicate that this test can be used as a helpful biomarker for the diagnosis of PCa in larger future studies.

Fidan et al. (16) reported elevation in serum IMA, malondialdehyde (MDA)-an oxidative stress marker-and oxidative stress index in patients with stomach cancer and claimed that this condition was related to the impaired balance between oxidative and antioxidant processes. In a more recent study, Huang et al. (24) have identified significant elevation in serum IMA concentrations in patients with preoperative stage III stomach cancer. The authors claimed that serum IMA levels could be an independent prognostic factor in operable advanced gastric cancer patients. In another study, Ellidag et al. (25) detected that serum IMA, total oxidation status and oxidative stress index were significantly higher in patients with colorectal cancer than in controls $(p<0.0001)$. Satoh et al. (26) reported that serum IMA levels in patients with colorectal cancer positively correlated with severity of the disease. In the literature, we found only one study investigating the relationship between prostatic diseases and IMA. In their study, Mastella et al. (17) investigated serum IMA in 27 patients with myocardial infarction (MI), 122 patients with benign prostatic hyperplasia (BPH) and 84 patients with PCa. Serum IMA levels were significantly higher in patients with $\mathrm{MI}$ and $\mathrm{BPH}$ than in control group. Although serum IMA levels were also higher in patients with PCa when compared to controls, the difference was not statistically significant. In this study, no subgroup analysis of Pca patients, nor clinical stage and GS score were mentioned. In another study, Ellidag et al. (27) found that serum IMA levels in patients with urinary bladder cancer were significantly high. Moreover, in their study including pediatric patients with soft tissue sarcomas and neuroblastoma, StachowiczStencel et al. (18) reported that serum IMA levels were higher in the patient group compared to the control group.

\section{Study Limitations}

The fact that our study was single-centered, the number of patients was relatively low and the other oxidative stress parameters were not considered could be considered a significant limitation. However, although there are many studies on the relationship 
between cancer and IMA in the literature, we think that it will contribute to the literature since there are very little research on the relationship between Pca and IMA. Moreover, we believe that higher IMA level in aggressive and advanced stage Pca and high sensitivity according to ROC analysis are important data. Future larger and multicenter studies may reveal more clearly whether IMA is a new biomarker and/or it has a prognostic value for Pca. This study may contribute to investigations on this matter.

\section{Conclusion}

Our data show that serum IMA levels are statistically significantly higher in especially advanced and aggressive Pca patients. Also, it was observed that serum IMA levels were positively correlated with PSA levels in Pca patients. Meanwhile, due to its high sensitivity (80\%), IMA can be used as an ancillary biomarker in diagnosis.

\section{Authorship Contributions}

Concept: R.A., M.S. Design: R.A., R.E., M.S. Data Collection or Processing: R.A., R.E., M.S., M.D., K.T. Analysis or Interpretation: R.E., M.S., M.D., K.T. Literature Search: R.A., R.E. Writing: R.A., M.S.

Conflict of Interest: No conflict of interest was declared by the authors.

Financial Disclosure: The authors declared that this study received no financial support.

\section{References}

1. Ferlay, J, Soerjomataram, I, Dikshit R, et al. Cancer incidence and mortality worldwide: Sources, methods and major patterns in GLOBOCAN 2012. Int J Cancer 2015;136:359-86.

2. Boyle P, Ferlay J. Cancer incidence and mortality in Europe, 2004. Ann Oncol 2005;16:481-8.

3. Jemal A, Siegel R, Ward E, et al. Cancer statistics, 2008. CA Cancer J Clin 2008;58:71-96.

4. Heidenreich A, Bellmunt J, Bolla M, Joniau S, Mason M, Matveev $V$. EAU guidelines on prostate cancer. Part 1: screening, diagnosis, and treatment of clinically localised disease. Eur Urol 2011;59:61-71.

5. Adhyam M, Gupta AK. A Review on the Clinical Utility of PSA in Cancer Prostate. Indian J Surg Oncol 2012;3:120-9.

6. Bokhorst LP, Bangma CH, van Leenders GJ. et al. Prostatespecific antigen-based prostate cancer screening: reduction of prostate cancer mortality after correction for nonattendance and contamination in the Rotterdam section of the European Randomized Study of Screening for Prostate Cancer. Eur Urol 2014;65:329-36.

7. Kretschmer A, Tilki D. Biomarkers in prostate cancer - Current clinical utility and future perspectives. Crit Rev Oncol Hematol 2017;120:180-93.
8. Schröder F. H, Hugosson J, Roobol M. et al. Screening and prostate cancer mortality: results of the European Randomised Study of Screening for Prostate Cancer (ERSPC) at 13 years of follow-up. Lancet 2014;384:2027-35.

9. Valko M, Rhodes CJ, Moncol J, Izakovic M, Mazur M. Free radicals, metals and antioxidants in oxidative stress-induced cancer. Chem Biol Interact 2006;160:1-40.

10. Khandrika L, Kumar B, Koul S, Maroni P, Koul HK. Oxidative stress in prostate cancer. Cancer Lett. Cancer Lett 2009;282:125-36.

11. Toyokuni S. Oxidative stress as an iceberg in carcinogenesis and cancer biology. Arch Biochem Biophys 2016;595:46-9.

12. Prasad S, Gupta SC, Pandey MK, Tyagi AK, Deb L. Oxidative Stress and Cancer: Advances and Challenges. Oxid Med Cell Longev 2016;2016:e5010423.

13. Roy D, Quiles J, Gaze DC, Collinson P, Kaski JC, Baxter GF. "Role of reactive oxygen species on the formation of the novel diagnostic marker ischaemia modified albumin. Heart 2006;92:113-4.

14. Sitar ME, Aydin S, Cakatay U. Human serum albümin and its relation with oxidative stress. Clin Lab 2013;59:945-52.

15. Ma Y, Kang W, Bao Y, Jiao F, Ma Y. Clinical Significance of Ischemia-Modified Albumin in the Diagnosis of DoxorubicinInduced Myocardial Injury in Breast Cancer Patients. PLoS One 2013;8:e79426.

16. Fidan E, Mentese A, Kavgaci $H$, et al. Increased ischemiamodified albumin levels in patients with gastric cancer. Neoplasma 2012;59:393-7.

17. Mastella AK, Moresco RN, Silva DB, et al. Evaluation of ischemia-modified albumin in myocardial infarction and prostatic diseases. Biomed Pharmacother 2009;63:762-6.

18. Stachowicz-Stencel T, Synakiewicz A, Owczarzak A, et al. Ischemia-modified albumin as a biochemical marker in children with neuroblastoma and soft tissue sarcomas. J Clin Lab Anal 2011;25:255-8.

19. Bar-Or D, Lau E, Winkler JV. A novel assay for cobalt- albumin binding and its potential as a marker for myocardial ischemia - a preliminary report. J Emerg Med 2000;19:311-5.

20. Ziech D, Franco R, Pappa A, Panayiotidis MI. Reactive oxygen species (ROS)-induced genetic and epigenetic alterations in human carcinogenesis. Mutat Res 2011;711:167-73.

21. Oh B, Figtree $G$, Costa $D$, et al. Oxidative stress in prostate cancer patients: A systematic review of case control studies. Prostate Int 2016;4:71-87.

22. Ahmed Amar SA, Eryilmaz R, Demir H, Aykan S, Demir C. Determination of oxidative stress levels and some antioxidant enzyme activities in prostate cancer. Aging Male 2018;15:1-9.

23. Mottet N, Bellmunt J, Bolla M, Briers E, Cumberbatch MG, De Santis M. EAU-ESTRO-SIOG Guidelines on Prostate Cancer. Part 1: Screening, Diagnosis, and Local Treatment with Curative Intent. Eur Urol 2017;71:618-29. 
24. Huang QX, Ma J, Wang YS. Significance of preoperative ischemia- modified albumin in operable and advanced gastric cancer. Cancer Biomark 2018;22:477-85.

25. Ellidag HY, Bulbuller N, Eren E. et al. Ischemia-modified albumin: could it be a new oxidative stress biomarker for colorectal carcinoma?. Gut Liver 2013;7:675-80.
26. Satoh M, Kotani K, Gugliucci A, Horie H, Caccavello R, Takeuchi M. Correlation of ischemia-modified albumin with SOFA and APACHE II scores in preoperative patients with colorectal cancer. ScientificWorld Journal 2014;2014:959075.

27. Ellidag HY, Eren D, Aydın O, et al. Ischemia modified albumin levels and oxidative stress in patients with bladder cancer. Asian Pac J Cancer Prev 2013;14:2759-63. 